\title{
ANALYSIS OF AUDIT MARKET AND AUDIT FIRMS ACTIVITY IN LITHUANIA
}

\author{
Jurate Steponaviciute \\ Algis Zvirblis ${ }^{2}$ \\ Liudmila Zumeriene ${ }^{3}$
}

\begin{abstract}
The paper presents an analysis of the Lithuanian audit market, its nature and concentrations, audit services amounts and distribution, and audit firms activities and their income based on the results of empirical research. Lithuanian Chamber of Auditors (LCA) maintains the functions of accumulation, summarizing and dissemination information on Lithuanian auditors and audit firms. LCA information is therefore, a rich source of data for researching and studying the development of the Lithuanian audit market. The summary of LCA membership lists was used to address the issue of the Lithuanian audit market concentration. Authors of the paper present the following major attitudes: concentration due to the subject of audit activity, historical grow and development of audit firms, auditors and position held by auditors; regional concentration due to legal forms of audit firms; concentration due to audit services, income from audit services as per legal form of audit clients, time spent on audits, strategies used in audit firms. All these criteria present scheme of the audit market concentrations that provides us with information about how the structures, legal forms and strategies of audit firm are changing and main reasons for this change.
\end{abstract}

Key words: audit market, audit market concentration, audit firms, audit activity income.

JEL codes: M42, L19.

\section{Introduction}

The structure of the audit market in the Eastern European Union countries is the result of a long-term process comprised of some firms operating and staying in business for long time, with others entering and exiting the market, the internal growth of firms, mergers between them, changes in their legal status and frequently changing legislative requirements in the audit sphere. All these aspects reflect on the "Pillars of Competitiveness" such as Institutions and Goods market efficiency: Institutions (ethical behavior of firms, strength of auditing and reporting standards) and Goods market efficiency (intensity of local competition, extent of market dominance) as defined in the World Economic Forum evaluations (below WEF, The Global ... 2010). According to the Global Competitiveness Report 2008 - 2009, the Baltic States of Lithuania and Latvia were much worse, whereas, Estonia, did not suffer as steep as a drop as its peers. This report provides detailed analysis of the national economies and, therefore provides impact to the national audit markets as well.

The main factors affecting the audit market in Lithuania in 2009 were the worldwide financial crisis and changes in legislative requirements. To respond to financial scandals and the experience of inappropriate audits during 2007-2008, significantly stricter requirements were implemented and the new EU Directive on Statutory Audit was approved. The Lithuanian Parliament decided not to establish a new separate body for public audit oversight, but delegated

\footnotetext{
${ }^{1}$ International School of Law and Business, Vilnius, Lithuania, jurate.steponaviciute@ttvam.lt

2 International School of Law and Business, Vilnius, Lithuania, algiszvirblis086@gmail.com

${ }^{3}$ International School of Law and Business, Vilnius, Lithuania, liudmila.zumeriene@ttvam.lt
} 
these functions to Authority of Audit and Accounting (AAA) with the purpose of establishing an independent system of regulation for the audit profession. The Lithuanian Chamber of Auditors (LCA) is a public legal entity unifying all certified auditors of Lithuania. "Auditor" denotes a person, who satisfies the requirements defined in the Law on Audit, holds the auditor's certificate and is a member of LCA. Quality assurance of audits carried out by auditors and audit firms in Lithuania is implemented by the AAA together with the LCA.

According to the Law on Audit (2008 year), when carrying out an audit of financial statements of the reporting period starting on 1 January 2009, and later the International Standards on Audit (ISA) and the Code of Ethics of Professional Accountants, issued by IFAC, shall apply. This legislative requirement obligated auditors to start applying International Standards on Audit on auditing of financial statements compiled from 1 January 2009 and International Standard on Quality Control 1 (ISQC1) for firms that perform audits and reviews of financial statements, and other assurance and related services engagements is effective as of December 15, 2009. While before, most small and medium Lithuanian audit firms were applying National auditing standards and implementing quality assurance systems in auditing companies in accordance with ISQC1, this was absolutely new. All these factors had a huge influence on the activities of audit firms and big impact on audit fees in the Lithuanian audit market, therefore impacted the audit market concentration as a whole.

\section{Literature review}

As S. Maijoor noted, "audit market concentration measurement has already received considerable attention in the audit research literature and developments in the level of concentration are documented in many studies (Zeff and Fossum, 1967; Schiff and Fried, 1976; Dopuch and Simunic, 1980). However, membership list data provide an opportunity to calculate concentration indices over a longer period, at more points in time, and for an almost complete audit market". (Maijoor et al., 1995). The conceptual provisions for the role of auditing and demand for auditing services (aproaching Estonian case) were discussed by K. Ittonen (Ittonen, 2010). An association between price and concentration, seller concentration in the market for audit services was investigated by Danos and Eichenseher $(1982,1986)$; pricing in industrial sectors was looked at by Francise (Francis, 1984; Palmrose, 1986; Francis and Simon, 1987; Ferguson et al., 2003); auditor independence in the Central and Eastern Europe region was investigated by Kosmala (Kosmala, 2007). Impact of audit firm mergers on market share was investigated by Francis et al. (1999). Menon and Williams (2001), Pong (2004) investigated audit firm mergers influence on audit fees.

The other theoretical and practical issues related to the audit activities were considered by foreign and Lithuanian scientists. Among them: a new approach to auditing and evaluation of financial statements (Mackevičius, 2009), audit quality assurance systems in auditing companies (Mackevicius and Kazlauskiene 2009), function of auditors, factors influencing the auditing state, reasons for fraud of financial statements and ways to prevent it (Lakis, 2008; Mackevicius and Kazlauskiene, 2009). The other studies measured market concentration and approaching audit pricing (Quick and Wolz, 1999; Wolk, Michelson and Wooton 2001; Willekens and Achmadi, 2003). The Lithuanian public auditing system was analyzed by J.Mackevicius and L. Pranckeviciute 2007; however those methods are not relevant in audit activities performed by external auditors in Lithuania.

As is clearly seen, many audit issues were examined but only fragmentary and there are not enough complex studies, therefore a closer examination of the audit market in Lithuania is very relevant. 


\section{Research methodology}

Methodologies of investigation: performed a theoretical review, analyzed available scientific literature, executed a study of the empirical research results and presented conclusions utilizing both systematized and generalized information.

Empirical research was applied to determine the concentration of the audit market as well as examining the subjects of this market by analyzing income dynamics - again utilizing both systematized and generalized information.

A process of logical synthesis was also applied in formulating prospects for improvement.

The goal of the examination is to determine distribution level of subjects to auditing activity and structure, dynamics of income from auditing and other services for 2008/2009. The object of the investigation is Lithuanian auditing services market. The population examined in this study consists of all audit firms and auditors in Lithuania. The investigation draws on publicly available information for 2008/2009 from LCA.

\section{Review of European Union audit market parameters}

Comparing the Global Competitiveness Index rankings from study periods 2010-2011 and 2009-2010, one could see Estonia's index of Extent of market dominance rose from 43 to 38, Romania fell from 39 to 59, Poland rose from 47 to 39, Lithuania fell from 81 to 97, Latvia fell from 57 to 70. To consider the index of Strength of auditing and reporting standards one could see Estonia's ranking fell from 18 to 26, Romania fell from 71 to 77, Poland rose from 60 to 46, Lithuania rose from 46 to 43, Latvia fell from 66 to 79. The largest country among the new European Union members, Poland, moves up to 39th. This significant improvement reflects the country's relatively strong resistance to the economic recession as a result of more clear and evident economic policies and its growing domestic market size. Due to the WEF data, Poland was the only European economy to register positive growth in 2009. The competitive advantage we can observe for Poland and Estonia's index of Extent of market dominance, and for Poland and Lithuania's index of Strength of auditing and reporting standards.

Stakeholders of company financial information are very concerned about the current market structure for the supply of audit services mainly for issues concerning audit price and quality to the extent that these two factors are influenced on competition in the market. The concern of these issues is also shown in the Directive 2006/43 EC Article 29 that refers to quality assurance systems and Article 32 that relates about principles of public oversight. As it is stressed in the Oxera report: Ownership rules of audit firms and their consequences for audit market concentration (p. 191) survey results of European Union member states' audit firms shows the importance of the role of public oversight bodies in monitoring the audit market, "however public oversight bodies in the European Union are unlikely to have a fundamental impact on the level of effective choice for companies tendering for audit services". The Big4 are prevailing in the audit market and no single company is protected from the possibility of failure. Authors of this paper, while analyzing the audit market concentration issues, would like to draw attention of public oversight bodies for the possibility of creating opportunities for new audit firms as well medium-sized audit firms to enter market for audit services for large public companies, listed companies and large private enterprises, creating prevention mechanisms to avoid the danger of possible financial scandals, fraudulent audits with falsified company information, while drawing attention to how to improve "healthy" competition in the audit market.

The most recent analysis of audit market concentration in EU Member States to our knowledge was implemented by Oxera on 2006 (table no. 1). 
Table No. 1

\begin{tabular}{|c|c|c|c|c|}
\hline \multirow{3}{*}{ Country } & \multicolumn{4}{|c|}{ Audit market concentration in EU Member States } \\
\hline & \multicolumn{2}{|c|}{$\begin{array}{l}\text { For companies in main index of } \\
\text { main national stock exchange }\end{array}$} & \multicolumn{2}{|c|}{ For all public companies } \\
\hline & $\begin{array}{c}\text { No. of } \\
\text { Companies }\end{array}$ & $\begin{array}{l}\text { HHI (by number } \\
\text { of mandates) }\end{array}$ & $\begin{array}{c}\text { No. of } \\
\text { Companies }\end{array}$ & $\begin{array}{l}\text { HHI (by } \\
\text { number of } \\
\text { mandates) }\end{array}$ \\
\hline Hungary & 12 & 4876 & - & - \\
\hline Spain & 35 & 4100 & 1805 & 696 \\
\hline Germany & 30 & 4022 & - & - \\
\hline Finland & 25 & 3984 & 127 & 2283 \\
\hline Cyprus & 20 & 3800 & 124 & 1951 \\
\hline Latvia & 5 & 3600 & 36 & 540 \\
\hline Slovakia & 5 & 3600 & - & - \\
\hline Malta & 14 & 3163 & - & - \\
\hline Poland & 20 & 3150 & 242 & 622 \\
\hline Czech Republic & 9 & 3000 & 37 & 284 \\
\hline Ireland & 20 & 3000 & 57 & 1571 \\
\hline Portugal & 20 & 3000 & - & - \\
\hline UK & 100 & 2912 & 1850 & 1057 \\
\hline Sweden & 30 & 2792 & - & - \\
\hline Austria & 22 & 2743 & - & - \\
\hline Italy & 40 & 2662 & - & - \\
\hline Netherlands & 23 & 2608 & 183 & 1832 \\
\hline Greece & 20 & 2550 & 318 & 2328 \\
\hline Lithuania & 21 & 2340 & 39 & 1689 \\
\hline Luxembourg & 11 & 2307 & - & - \\
\hline Estonia & 10 & 2200 & 15 & 2444 \\
\hline Belgium & 19 & 2031 & 140 & 788 \\
\hline Slovenia & 15 & 2000 & - & - \\
\hline Denmark & 19 & 1833 & 126 & 1611 \\
\hline France & 40 & 1818 & - & - \\
\hline
\end{tabular}

Source: Oxera 2006.

Note: For the measure of concentration for all public companies, there was incomplete information for some countries. Countries have been ranked by HHI for the companies in the main index of the main national stock exchange, from highest to lowest. The HHI is calculated by adding up the squares of the market shares of all auditors. It ranges between 0 (numerous market participants with very low market shares) and 10,000 (monopoly with $100 \%$ market share). For example, in a market with five firms, each with $20 \%$ of the market, the HHI is 2,000. According to the US merger guidelines, an HHI above 1,800 indicates that the market is highly concentrated, and a market with an HHI between 1,000 and 1,800 is moderately concentrated. See Department of Justice and Federal Trade Commission (1992), 'Horizontal Merger Guidelines' (revised in 1997).

Audit market concentration has increased over time in all EU member states due to a combination of mergers of leading and prevailing Big Four firms in the audit market. The analytical work done by Oxera Consulting Ltd (2006) showed that the Big Four firms charge higher fees than the small and medium-sized firms. The main barrier for entry and expansion of audit firms are ownership rules and strict quality assurance systems requirements for audit firms. However, as pointed by the Oxera Consulting Ltd (2006), key barriers to Non-B4 audit firms entering the market 
include lack of reputation and recognition, resources including effective capability to assure timely and reliable audit opinion.

Further, this paper will examine the Lithuanian audit market in more details.

Analysis of subjects to auditing activity.

According to the summary of LCA membership lists data in 2009 there were 413 certified auditors, members of LCA (hereinafter referred to as the auditors) that hold the title of the certified auditor of the Republic of Lithuania, that gives the right to perform audits of financial statements (hereinafter - an audit) and 416 persons seeking auditor's title and entered in the list of auditor's assistants at the end of 2009. This study shows almost equal number of certified auditors that are working in auditing practice and implementing audit as well as auditor's assistants also working in auditing sphere. While the number of auditors is increasing at a very low rate it suggests that auditor's assistants are either satisfied with their position and are not willing to achieve certified auditor's title or the exams for auditor's accreditation are too strict and hence, entry level to the market is very low.

The list of audit firms is comprised of 193 companies (hereinafter - the audit firm) registered in Lithuania (there were not obtained applications from companies registered in other countries to be registered on the list of audit firms in Lithuania). In accordance with the Law on Audit of the Republic of Lithuania, the auditor can only perform audits if they are: owner of an individual audit firm (10 percent of all auditors), working in an auditing firm (56 percent). It is clear that the number of auditors is increasing while the number of audit firms is decreasing compared with previous years. As described in the theoretical part of this study, the reasons for the decreasing amount of audit firms are due to factors such as mergers in response to tight competition in the market, the stricter requirements of ISQC1 and business leaving the audit field due to their inability to compete in the market (fig. No. 1).

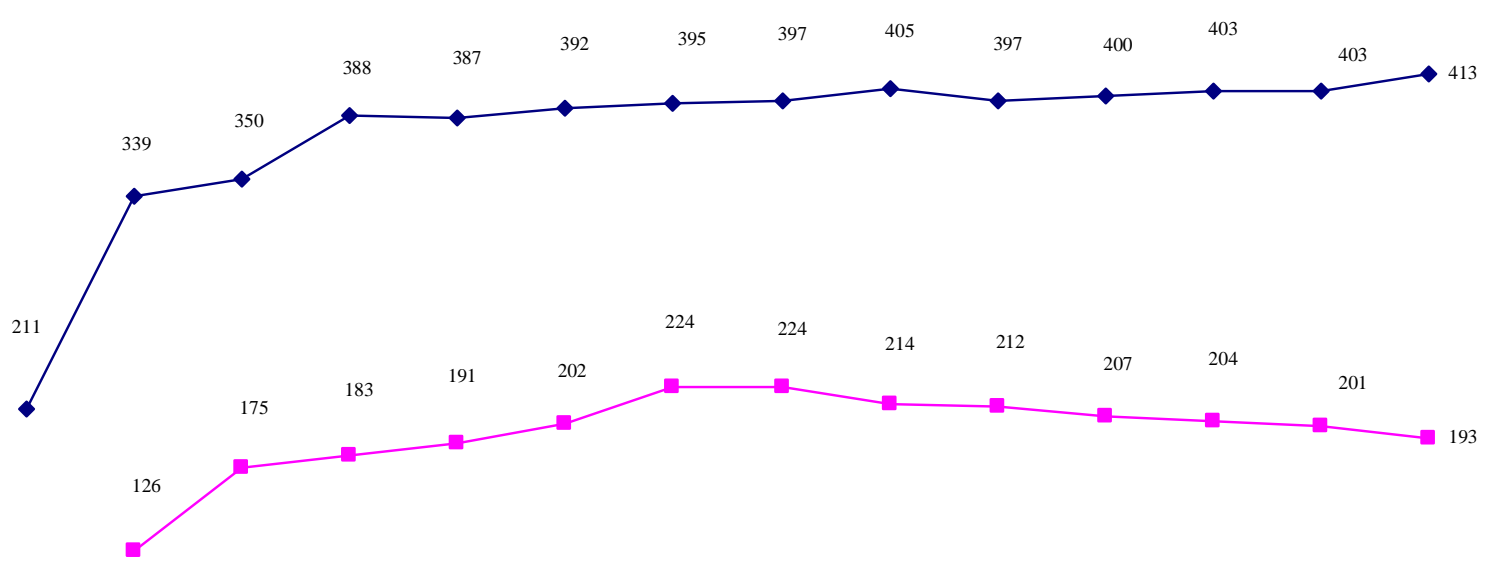

$19961231 \quad 19971231 \quad 19981231 \quad 19991231 \quad 20001231 \quad 20011231 \quad 20021231 \quad 20031231 \quad 20041231 \quad 20051231 \quad 20061231 \quad 20071231 \quad 20081231 \quad 20091231$

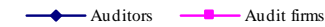

Fig. no. 1 - Number of auditors and audit firms

Source: LCA, Review of audit market 2009 
In accordance with LCA membership data 46 percent of auditors are working as CEO of audit firms and 19 percent of auditors are working in audit companies, 23 percent of auditors are working in private sector, and 9 percent in governmental sector. Three percent of auditors are unemployed. These data shows that only 65 percent of auditors are working in the audit industry. The auditing business is not deemed attractive for 35 percent of auditors and in addition to that there is a percentage of unemployed. These factors demonstrate that the auditing business in Lithuania is not very attractive for Lithuanian certified auditors. They prefer to work in other industries even though the auditor must continually develop his professional qualification through auditors professional courses (each three consecutive years must hear not less than 120 hours of courses or attend equivalent courses in development the professional qualifications).

In 2009 there were 541 thousand hours, at an average of 147 hours for one audit (Table no. 2 ). The increase in revenues from audit (4 percent) was influenced by factors such as decrease in the number of audits ( -6 percent.) and increase in audit price ( 15 percent). As the average price for an audit increases and the average time spent on the performance of the audit decreases this results increased price for audits per hour: for all audit firms - 130 LTL / hour. In 2009 this rate was 112 LTL / hour. Excluding the Big Four audit firms, this assessment would be - 83 LTL / hour. In 2009 this rate was 79 LTL / hour. Since the average number of employees in audit firms increased and earnings of audit companies declined, the average revenue per audit firm employee declined (-9 percent). Even though fees increased in 2009 due to the quality assurance fulfillment requirements and changes of International standards on audit implementation expenses, but due financial crisis influence on economic activity, many audit firms clients - companies where audit was not legislatively obligated - declined to receive services, resulting in many bankruptcies and an overall decrease of audits number in Lithuania.

Table no. 2

Resources of audit firms per number of working auditors in audit firms (2009)

\begin{tabular}{|l|c|c||c|c||c|c|}
\hline & $\begin{array}{c}\text { Time } \\
\text { spent on } \\
\text { one audit, } \\
\text { in hours }\end{array}$ & $\begin{array}{c}\text { Change, } \\
\text { in } \\
\text { \% }\end{array}$ & $\begin{array}{c}\text { Price } \\
\text { per } \\
\text { audit, } \\
\text { LTL }\end{array}$ & $\begin{array}{c}\text { Change, } \\
\text { in } \\
\%\end{array}$ & $\begin{array}{c}\text { Audit firm } \\
\text { revenue per } \\
\text { employee per } \\
\text { month, LTL }\end{array}$ & $\begin{array}{c}\text { Change, } \\
\text { in } \\
\%\end{array}$ \\
\hline $\begin{array}{l}\text { Audit firms with one } \\
\text { working auditor }\end{array}$ & $\mathbf{1 1 0}$ & $\mathbf{1 , 9}$ & $\mathbf{7 7 6 4}$ & $\mathbf{- 1 0 , 9}$ & $\mathbf{4 5 0 1}$ & $\mathbf{- 2 5 , 6}$ \\
\hline $\begin{array}{l}\text { Audit firms with } \\
\text { working auditors }\end{array}$ & $\mathbf{1 0 5}$ & $\mathbf{- 2 1 , 1}$ & $\mathbf{8 7 1 8}$ & $\mathbf{- 0 , 8}$ & $\mathbf{4 7 4 7}$ & $-\mathbf{1 6 , 4}$ \\
\hline $\begin{array}{l}\text { Audit firms with 3 and } \\
\text { more working auditors }\end{array}$ & $\mathbf{1 2 5}$ & $\mathbf{- 3 , 1}$ & $\mathbf{1 1 4 9 0}$ & $\mathbf{1 , 4}$ & $\mathbf{6 9 9 3}$ & $-\mathbf{1 3 , 6}$ \\
\hline Big Four & $\mathbf{2 5 8}$ & $\mathbf{4 , 5}$ & $\mathbf{5 2 1 8 4}$ & $\mathbf{2 6 , 9}$ & $\mathbf{1 8 1 1 5}$ & $\mathbf{- 9 , 7}$ \\
\hline Total & $\mathbf{1 4 7}$ & $\mathbf{- 1 , 3}$ & $\mathbf{1 9 2 0 7}$ & $\mathbf{1 5 , 2}$ & $\mathbf{9 5 8 2}$ & $\mathbf{- 9 , 1}$ \\
\hline
\end{tabular}

Source: LCA, Review of audit market 2009

In accordance with LCA membership data in 2009 the price per one assurance service was 9302 LTL and 6476 LTL in 2008. The average time spent for assurance service was 77 hours in 2009 and 49 hours in 2008.

Depending on the legal status of the audit client, in 2009 there were different average times spent on each audit: public interest companies - 269 hours/ audit; companies, where an audit is an obligatory requirement (public interest companies excluded) - 155 hours/audit; companies where audit is not an obligatory requirement - 99 hour/audit. 221 audit firms spent from 50 to 100 hours/audit and only 5 audit firms spent more than 400 hours/audit in 2009. It should not be 
concluded that more hours spent performing an audit necessarily means better quality. Sometimes "more" is required for special purposes or providing companies with special services, so that the time spent on an audit exceeds the time planned in the audit scheduler and this influences the audit price.

\section{Assessment of audit firms concentration level}

This section analyses the concentration level of auditing companies.

Most audit firms are established in major cities of Lithuania: Vilnius - 107, Kaunas - 38, Klaipeda - 12. Meanwhile, other cities set up only 36 audit firms. Compared to the regions as well most audit firms are established in Vilnius (56 percent of all audit firms), Kaunas (20 percent) and Klaipeda (8 percent) (Fig. no. 2).

The distribution of audit firms reflect the industrial and business distributions across the Republic of Lithuania and is therefore most closely associated with the large economic urban centers where the demand is strongest for such services.

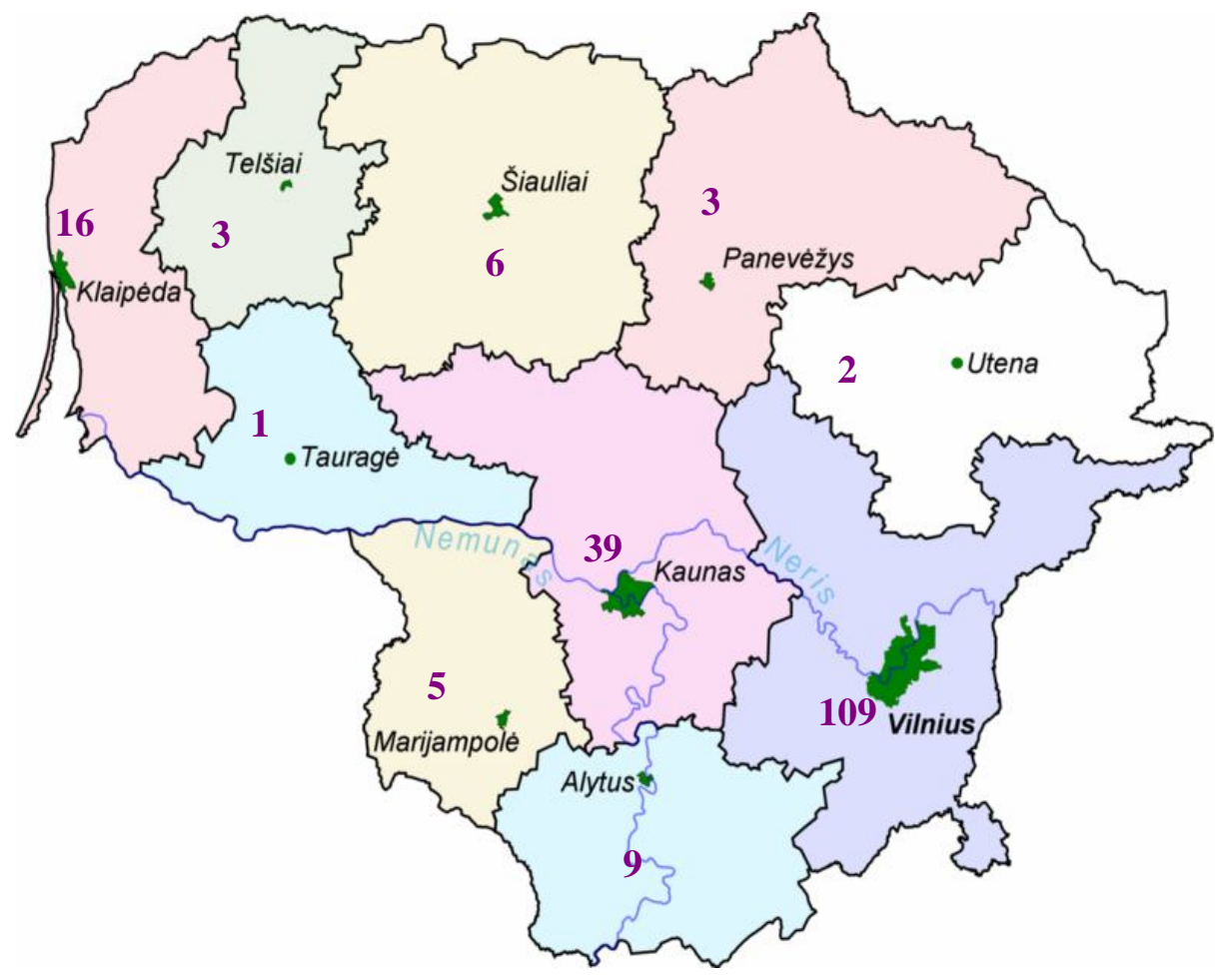

Fig. no. 2 - Audit firms distribution according regions Source: LCA, Review of audit market 2009

The number of audit firms in accordance with the legal form of audit firms over the period of activity evolved differently (Fig. no. 3):

- The number of limited liability companies continually increased and it comprised 78 percent of all audit firms at the end of 2009 while it comprised only 45 percent in 1997;

- The number of private companies increased till 2002, afterwards it started to decline until it comprised 21 percent of all audit firms at the end of 2009. In 1997 they comprised 47 percent;

- The number of general partnerships increased only till 1999, afterwards they started to decline and there remained just 2 at the end of 2009 without a single limited partnership remaining. 


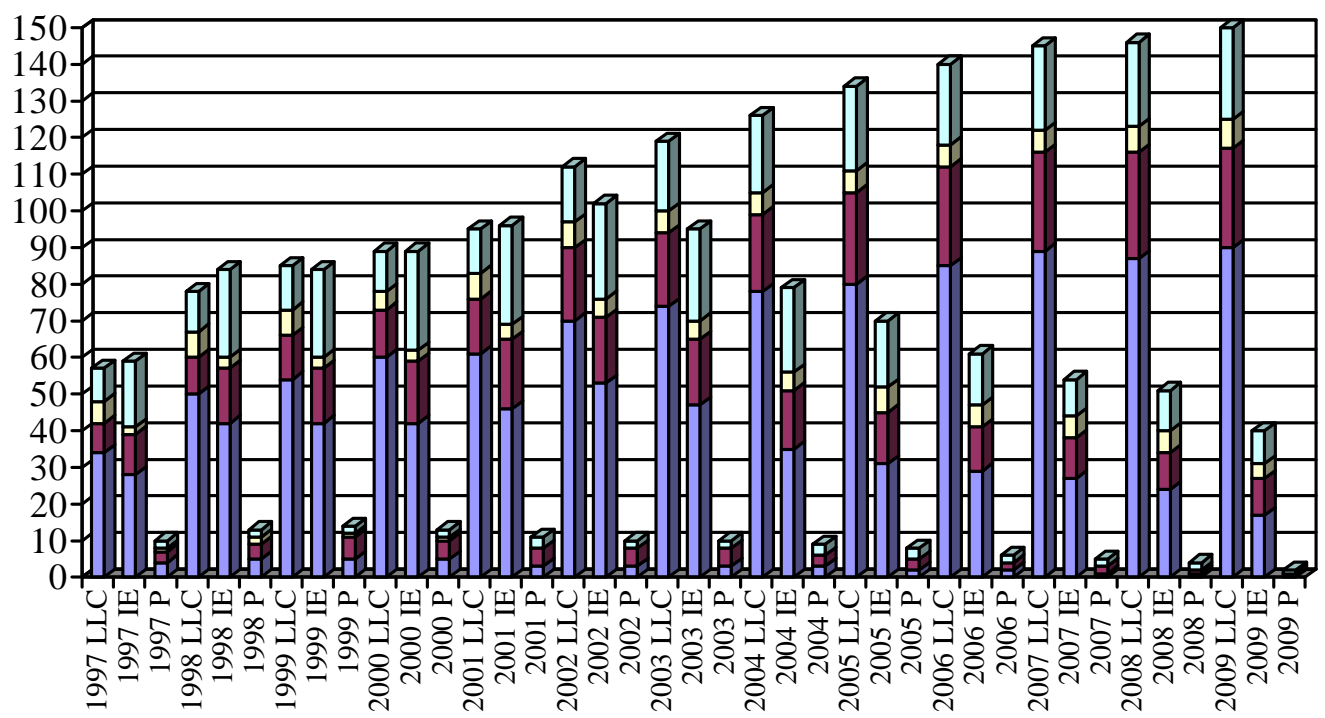

$\square$ Vilnius $\square$ Kaunas $\square$ Klaipeda $\square$ Other towns

Fig. no. 3. - Number of audit firms according their legal forms and towns LLC- limited liability company, IE - individual enterprise, $\mathbf{P}$ - partnership. Source: LCA, Review of audit market 2009

In accordance with LCA membership data, taking into account changes in the Lithuanian tax system, as well as on other grounds, during the first four months of 2010 joint stock companies continued to grow - increased by 15 audit firms, and private companies decreased by 13 and partnerships decreased by 1 . Due fact that the taxation system in Lithuania changed for private companies in the beginning of 2009, those companies were forced to reorganize to form limited liability companies to avoid possible larger taxation amount. So the statistics do not show new entries to the audit market but only the same participants changing their legal status.

Most of audit firms have only one auditor. During 2009, 67 percent of audit firms had only one auditor, audit firms with two auditors composed 18 percent, audit firms with three auditors - 11 percent, audit firms with 4 and more auditors - 4 percent. During 2009 on average audit firms employed 8.4 workers (fig. no. 4).

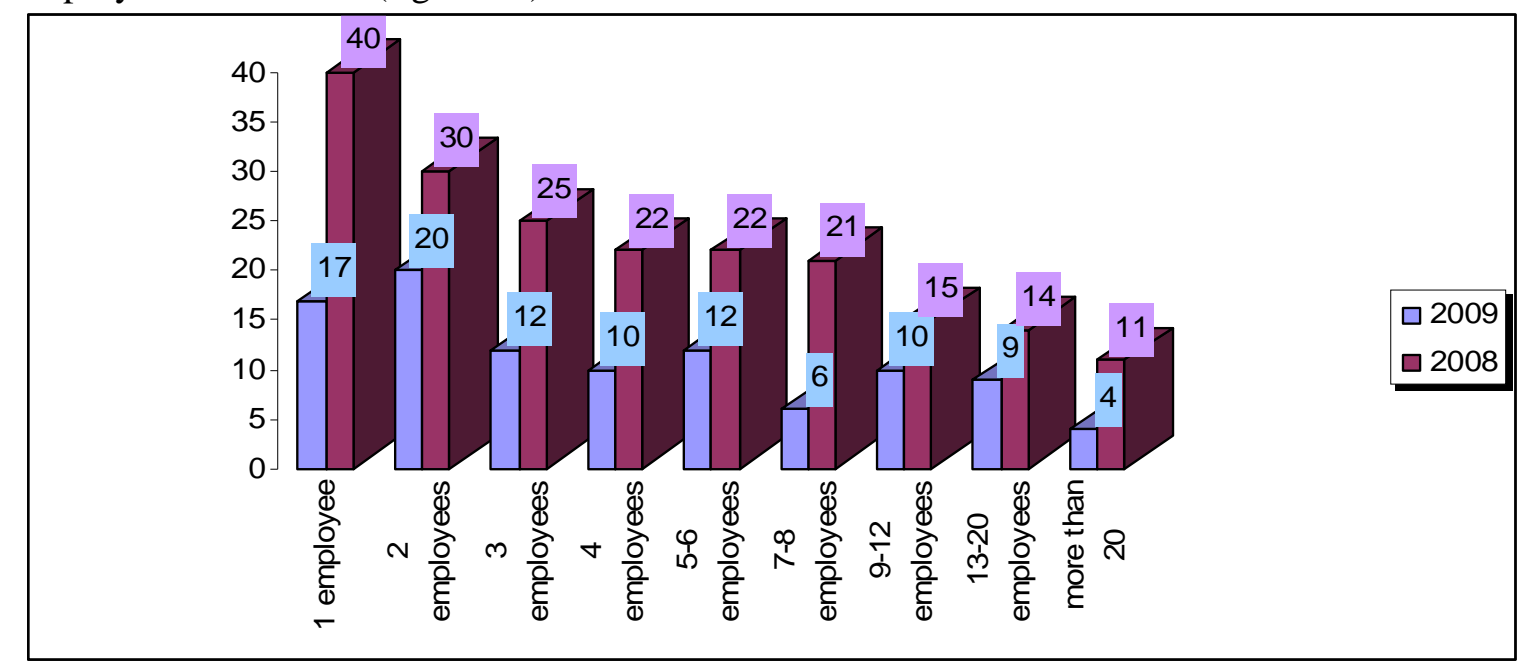

Fig. no. 4. - Distribution of audit firms by number of employees, in percents 
The provided data shows that 20 percent of audit firms employed two auditors and 17 percent of audit firms still have only one auditor. Audit firms with only one auditor are neither efficient nor effective participants in the audit market and experience numerous barriers in complying with legislative and ISQC1 requirements. Therefore, such firms have to cooperate with other audit firms or auditors in order to comply with quality assurance requirements and implement audit quality control systems.

\section{Analysis of structure of audit scope and income.}

In 2009 there were performed 3675 annual audits in the Republic in Lithuania (Table no.3) and 1508 other reviews and assurance services. The number of performed annual audits in 2009 fell by 6 percent in comparison with the previous year.

Table no. 3

Number of performed annual audits according to the number of auditors employed in audit firms and legal status of audit clients (2009 compared with 2008)

\begin{tabular}{|l|c|c|c|c|c|c|c|c|c|c|}
\hline & $\begin{array}{c}1 \\
\text { audi- } \\
\text { tor }\end{array}$ & $\begin{array}{c}\mathbf{2} \\
\text { audi- } \\
\text { tors }\end{array}$ & $\begin{array}{c}\text { 3 and } \\
\text { more } \\
\text { auditors }\end{array}$ & \multicolumn{2}{|c|}{$\begin{array}{c}\text { Total (Big4 } \\
\text { excluded) }\end{array}$} & \multicolumn{2}{|c|}{ Big4* } & \multicolumn{2}{|c|}{$\begin{array}{c}\text { Total } \\
\text { Pre- } \\
\text { vious } \\
\text { period }\end{array}$} & $\begin{array}{c}\text { Chan- } \\
\text { ge }\end{array}$ \\
\hline $\begin{array}{l}\text { Public interest } \\
\text { entities }\end{array}$ & 3 & 13 & 10 & 26 & $16 \%$ & 133 & $84 \%$ & 159 & 140 & $14 \%$ \\
\hline $\begin{array}{l}\text { Other public } \\
\text { limited liability } \\
\text { companies }\end{array}$ & 82 & 49 & 62 & 193 & $80 \%$ & 49 & $20 \%$ & 242 & 261 & $-7 \%$ \\
\hline $\begin{array}{l}\text { State and } \\
\text { municipal } \\
\text { enterprises }\end{array}$ & 74 & 73 & 42 & 189 & $94 \%$ & 13 & $6 \%$ & 202 & 198 & $2 \%$ \\
\hline $\begin{array}{l}\text { Limited liability } \\
\text { companies, } \\
\text { (obligatory } \\
\text { audit) }\end{array}$ & 571 & 361 & 628 & 1560 & $74 \%$ & 551 & $26 \%$ & 2111 & 2255 & $-6 \%$ \\
\hline $\begin{array}{l}\text { Other } \\
\text { companies, that } \\
\text { has obligatory } \\
\text { for being audited }\end{array}$ & 40 & 28 & 30 & 98 & $99 \%$ & 1 & $1 \%$ & 99 & 128 & $-23 \%$ \\
\hline $\begin{array}{l}\text { Other limited } \\
\text { liability } \\
\text { companies }\end{array}$ & 167 & 121 & 306 & 594 & $88 \%$ & 79 & $12 \%$ & 673 & 746 & $-10 \%$ \\
\hline Other companies & 63 & 53 & 63 & 179 & $95 \%$ & 10 & $5 \%$ & 189 & 174 & $9 \%$ \\
\hline \multicolumn{1}{|c|}{ Total: } & 1000 & 698 & 1141 & 2839 & $77 \%$ & 836 & $23 \%$ & 3675 & 3902 & $-6 \%$ \\
\hline Previous period & 1351 & 773 & 894 & 3018 & $77 \%$ & 884 & $23 \%$ & 3902 & & \\
\hline Change & $-26 \%$ & $-10 \%$ & $28 \%$ & $-6 \%$ & & $-5 \%$ & & $-6 \%$ & & \\
\hline
\end{tabular}

* UAB „DELOITTE LIETUVA“, UAB „ERNST \& YOUNG BALTIC“, „KPMG Baltics“, UAB and UAB

"PricewaterhouseCoopers"

Source: LCA, Review of audit market 2009

The effects of the economic recession resulted in a decrease for audit services. The reduced demand increased competition among audit firms that resulted in a reduction of audit firms (there were bankruptcy cases). Small audit firms (employing 1-2 auditors) declined by 20 percent, but medium-sized audit firms (employing 3 and more auditors) became stronger and increased their number of performed audits. The results show that Non-Big4 firms perform audits in other public limited liability companies (80 percent), state and municipal enterprises ( 94 percent), and other 
companies, while the Big Fours firms prevail in auditing of public interest entities ( 84 percent). Usually public interest entities are of significant public relevance because of the nature of its business, their size or the number of clients. A public-interest entity shall be public company whose securities are traded in the regulated market of the Republic of Lithuania and/or any other member state; these can include banks and the Central Credit Union; brokerage houses; investment company with variable capital and closed-end investment fund whose property management has not been transferred to management firm; firms of management of undertakings of collective investment and/or pension fund/funds; insurance undertaking and reinsurance undertakings. These companies usually require audits of Big Four companies to ensure reputable audit report because those companies are of significant public relevance.

The audit firms received 183 million LTL revenue from auditing activity in 2009 , ten percent less than in 2008 year (table no. 4).

Income of audit firms according to the auditors employed in audit firms and audit services, Million LTL (2009 compared with 2008)

\begin{tabular}{|c|c|c|c|c|c|c|c|c|c|c|}
\hline \multirow{2}{*}{$\begin{array}{l} \\
\text { Audit } \\
\text { (including } \\
\text { interim and } \\
\text { consolidated) }\end{array}$} & \multirow{2}{*}{$\begin{array}{c}\begin{array}{c}1 \\
\text { audi- } \\
\text { tor }\end{array} \\
7,8\end{array}$} & \multirow{2}{*}{$\begin{array}{c}\begin{array}{c}2 \\
\text { audi- } \\
\text { tors }\end{array} \\
6,1\end{array}$} & \multirow{2}{*}{$\begin{array}{c}\begin{array}{c}3 \text { and } \\
\text { more } \\
\text { auditors }\end{array} \\
13,1\end{array}$} & \multicolumn{2}{|c|}{$\begin{array}{c}\text { Total (Big } 4 \\
\text { excluded) }\end{array}$} & \multicolumn{2}{|c|}{ Big 4} & \multirow{2}{*}{\begin{tabular}{|l|} 
Total \\
70,6 \\
\end{tabular}} & \multirow{2}{*}{$\begin{array}{c}\begin{array}{c}\text { Pre- } \\
\text { vious } \\
\text { period }\end{array} \\
67,7\end{array}$} & \multirow{2}{*}{$\begin{array}{c}\begin{array}{c}\text { Chan- } \\
\text { ge }\end{array} \\
4 \%\end{array}$} \\
\hline & & & & 27,0 & $38 \%$ & 43,6 & $62 \%$ & & & \\
\hline $\begin{array}{l}\text { Assurance } \\
\text { and other } \\
\text { related } \\
\text { services }\end{array}$ & 0,6 & 0,7 & 2,1 & 3,4 & $50 \%$ & 3,4 & $50 \%$ & 6,8 & 12,3 & $-45 \%$ \\
\hline $\begin{array}{l}\text { Other } \\
\text { inspections }\end{array}$ & 0,6 & 0,5 & 1,3 & 2,4 & $44 \%$ & 3,0 & $56 \%$ & 5,4 & 13,8 & $-61 \%$ \\
\hline $\begin{array}{l}\text { Accounting } \\
\text { services }\end{array}$ & 12,4 & 4,2 & 11,5 & 28,1 & $78 \%$ & 7,9 & $22 \%$ & 36,0 & 35,8 & $1 \%$ \\
\hline $\begin{array}{l}\text { Consulting } \\
\text { services }\end{array}$ & 1,2 & 0,9 & 3,6 & 5,7 & $9 \%$ & 54,6 & $91 \%$ & 60,3 & 69,5 & $-13 \%$ \\
\hline Other activity & 1,5 & 1,0 & 1,4 & 3,9 & $100 \%$ & 0,0 & $0 \%$ & 3,9 & 3,4 & $15 \%$ \\
\hline Total: & 24,1 & 13,4 & 33,0 & 70,5 & $39 \%$ & 112,5 & $61 \%$ & 183,0 & 202,5 & $-10 \%$ \\
\hline $\begin{array}{l}\text { Previous } \\
\text { period }\end{array}$ & 41,4 & 19,9 & 24,9 & 86,2 & $43 \%$ & 116,3 & $57 \%$ & 202,5 & & \\
\hline Change & $-42 \%$ & $-33 \%$ & $33 \%$ & $-18 \%$ & & $-3 \%$ & & $-10 \%$ & & \\
\hline
\end{tabular}

Source: LCA, Review of audit market 2009

In accordance with LCA membership data in 2009, as compared with the previous year, the income of audit firms from the European Union structural fund projects and other reviews was reduced nearly by half. However income from accounting services remained stable, and income from audit services despite the overall decrease in the number of audits, increased by 4 percent. Income from audit activity was again the main source of income for audit firms.

The results show total drop-off income in all kinds of income. However audit firms with three and more auditors were able to increase their income by 33 percent compared with previous period when even Big Four firms suffer a drop off of 10 percent. This fact means that Non-Big4 firms with three and more auditors seem able to acquire their market share and be competitive in the audit market and maybe even profitable during the financial crisis period.

The audit firms' income and number of performed audits where increasing up till 2009. However, only income from audits increased in 2009. The number of audits performed by Big Four 
firms differs from Non-Big4 firms by more than three times and this ration remains same during last years. The results show that the largest share in income is income from other activities performed by Big Four firms.

Audit firms owned by Lithuanian auditors earned most income in 2009, however 37, 5 percent of audit income belong to persons from other countries. Despite fact that only 19 audit firms belongs to the audit network, they have $3 / 4$ of audit market (table no. 5 ).

Table no. 5

Distribution of audit firms income, percent (2009)

\begin{tabular}{|l|c|c|c|}
\hline & Audit & $\begin{array}{c}\text { Total other } \\
\text { services }\end{array}$ & Total \\
\hline $\begin{array}{l}\text { Income share of audit firms that belongs } \\
\text { to Lithuanian auditors (participants of } \\
\text { audit firms) }\end{array}$ & $\mathbf{5 0 , 8}$ & $\mathbf{6 7 , 4}$ & $\mathbf{6 1 , 0}$ \\
\hline $\begin{array}{l}\text { Income share of audit firms that belongs } \\
\text { to other Lithuanian persons (participants } \\
\text { of audit firms) }\end{array}$ & $\mathbf{1 , 5}$ & $\mathbf{1 , 5}$ & $\mathbf{1 , 5}$ \\
\hline $\begin{array}{l}\text { Income share of audit firms that belongs } \\
\text { to persons from other countries } \\
\text { (participants of audit firms) }\end{array}$ & $\mathbf{4 7 , 7}$ & $\mathbf{3 1 , 1}$ & $\mathbf{3 7 , 5}$ \\
\hline Income of audit network firms & $\mathbf{7 4 , 6}$ & $\mathbf{7 4 , 9}$ & $\mathbf{7 4 , 8}$ \\
\hline $\begin{array}{l}\text { Income of audit firms not belonging to } \\
\text { audit networks }\end{array}$ & $\mathbf{2 5 , 4}$ & $\mathbf{2 5 , 1}$ & $\mathbf{2 5 , 2}$ \\
\hline
\end{tabular}

Source: LCA, Review of audit market 2009

As previous study results shows that audit firms from audit network own $3 / 4$ of audit market, the results of income distribution shows that they earn 74,8 percent of all income and are prevailing as well in audit and in other services.

\section{Concluding notes}

The presentation has two aspects. The first aspect is to provide possible explanations for observed changes in the level of Lithuanian audit market concentration. The second aspect is to suggest the possibility of further comparative research with other countries that possess auditor association membership lists summaries as being a worthwhile and informative undertaking.

The first idea was to observe the audit market concentration level due to subjects of audit activity, historical growth and development of audit firms, auditors, and position held by auditors. This study shows an increase of auditors and audit firms from 1996 to 2003 in Lithuania. After 2003, there is observed a permanent decrease in audit companies in Lithuania. In the opinion of the authors, this decrease was influenced when the Republic of Lithuania joined the European Union (EU) on 1 May 2004. New EU legislation changed national legal norms as well as audit legislative and auditors in Lithuania were faced with stricter requirements of audit performance (such as ownership requirements, audit documentation, audit report issues). With the legislative requirements getting stricter all over EU, this resulted in a permanent decrease of audit companies. The number of auditors is increasing while the number of audit firms is decreasing from 2004. Auditors are leaving audit activity, some of them through mergers to satisfy quality control for audits and reviews of financial statements, and other assurance and related services engagements requirements and legal requirements. Meanwhile audit companies have to present quality and feasible fee audit services for their clients to remain competitive in the audit services market. Merger of small and medium audit firms would lead to quality performance of audit, limitation of fraud and error, risk management control, time spent on audit and earnings compliance and other benefits. 
Second idea is to observe regional concentration due to the legal form of audit firms. With the number of limited liability companies always was increasing, at the end of 2009 it consisted of 78 percent of all audit firms. The number of individual enterprises (sole proprietorship) was increasing only up to 2002 but since 2009, it represents only 21 percent of all audit firms. Since 2009, many individual enterprises changed their legal form to limited liability companies. This trend continues to be followed in first quarter of 2010 as well. This factor demonstrates the strategies small individual enterprises have been employing (merging or becoming a member of a network) in order to acquire and maintain a sizeable market share. The decrease of individual enterprises in the audit market is good sign for quality and audit fee factors.

Third idea was to observe the concentration related to audit services, income from audit services comprised by different legal status of audit clients, time spent on audit, strategy used in audit firm. The number of performed annual audits in 2009, declined by 6 percent in comparison with previous year. The reduced demand increased competition amongst audit firms that resulted in reduction of audit firms (there were bankruptcy cases). Small audit firms (employing 1-2 auditors) declined by 20 percent, but medium-sized audit firms (employing 3 and more auditors) got stronger and increased their number of performed audits. Comparative analysis of the income structure of audit firms reveals that Big 4 dominate in the market for audit services (62 percent of all income) and consulting services (91 percent of all income); other audit firms income from audit services constitutes 38 percent and from consulting services 9 percent. (It is quite the opposite situation with regard to accounting services. The Big Four firms' income from accounting services constitutes 22 percent, while other audit firms' income from accounting services constitutes of 78 percent of all income.) This distribution of income shows that the Big Four companies as well dominating world wide, dominate in the Lithuanian audit market. In 2009, 24 audit firms did not perform audit. In 2008 there were 19 of such audit firms. These audit firms were perhaps unable to get audit engagements, especially as some audit firms specialize in certain industries, allowing them to become market leader in certain segment.

According to the issue of Accountancy Magazine published in June 2009 the audit market concentration increase (20-30\%) occurred worldwide. It is clear to see that the Big Four companies continue to dominate in the market, earning greater respect among clients. As a consequence of the economic recession more companies are looking for lower audit price and better quality. Therefore our findings suggest that the Non-Big4 firms would clearly benefit from rebalancing their client portfolios (as they usually serve more risky clients, less profitable clients, clients that usually coming from Big 4), to a more secure balance taking into account what they are able to do today as well as developing future prospects and capabilities for the future.

To further investigate these issues in a wider context and as possibility for comparative research, authors would like to offer as a further research subject whether the changes in European Union regulations have same impact on the levels of audit market concentration and/or how auditors adapt to these legal requirements and changes in quality control requirements through the European Union. This would contribute many new variables to audit market researches and provide more insight about the audit market concentration level in the European Union. The study can be further extended by investigating the sensitivity of the results using alternative specific concentration level measures such as Herfindahl index and Gini coefficient.

\section{References}

1. Audit market review 2009 [Audito rinkos apzvalga, 2009], available online at http://www.lar.lt/new/page.php?471 (accessed August 1, 2010).

2. Danos, P., Eichenseher, J., 1982. Audit Industry Dynamics: Factors Affecting Changes in Client-Industry Market Share. Journal of Accounting Research, pp. 604-616.

3. Danos, P., Eichenseher, J., 1986. Long-Term Trends towards Seller Concentration in the U.S. Audit Market. The Accounting Review, pp. 633-650. 
4. Directive 2006/43/EC of the European parliament and of the Council on statutory audits of annual accounts and consolidated accounts, available online at http://www.deti.ie/commerce/companylawlegislation/2006-43-EC.pdf (accessed September 21, 2010).

5. Dopuch, N., Simunic, D., 1980. The Nature of Competition in the Accounting Profession: A Descriptive and Normative View, in J. Buckly and J. Weston (eds). Regulation and lhe Accounting Profession. Lifetime Learning.

6. European Commission (2007), Directorate General for Internal Markets and Services, Consultation on Auditor's Liability - Summary Report, 18 June.

7. Ferguson, A., Francis, J.R., Stokes, D.J., 2003. The effects of firm-wide and office-wide level industry expertise on audit pricing. The Accounting Review, Vol. 78, No. 2, pp. 42948.

8. Francis, J., 1984. The Effect of Audit Firm Size on Audit Prices: A Study of the Australian Market. Journal of Accounting and Economics, pp. 131-151.

9. Francis, J., Simon, D., 1987. A Test of Audit Pricing in the Small-Client Segment of the U.S. Audit Market. The Accounting Review, pp. 145-157.

10. Francis, J.R., Stokes, D.J., Anderson, D., 1999. City markets as a unit of analysis in audit research and the re-examination of Big 6 market shares. Abacus, Vol. 35, No. 2, pp. 185 393.

11. Ittonen, K., 2010. A Theoretical Examination of the Role of Auditing and the Relevance of Audit Reports, VAASA, pp. 51.

12. Kosmala, K., 2007. (Un)realised Independence in the CEE Region: Insights from Interpretive Cultural Theory. Critical Perspectives on Accounting, 18(3), pp. 315-342.

13. Lakis, V., 2008. Independent auditing development tendencies. Technological and economic development of economy. ISSN 1392-8619. 2008, t. 14, No. 2, pp. 171-183.

14. Lakis, V., 2008. The Danger of Falsifying Information about Company and Ways to Prevent it [Melagingos informacijos apie imone keliama gresme ir jos prevencija]. Economics and Management: Issues and Perspectives. ISSN 1648-9098. No. 4(13), pp. 261-271.

15. Mackevicius, J., 2009. Auditing and Analysis of Financial Statements: Procedures, Methodology and Evaluation. Monograph [Finansiniu ataskaitu auditas ir analize: proceduros, metodikos ir vertinimas: monografija]. Vilnius, TEV. 389 p. ISBN 9789955879497.

16. Mackevicius, J., Kazlauskiene, L., 2008. Litewski system kontroli jakosci audytu i jego udoskonałanie. Zeszyty Teoretyczne Rachunkowości. ISSN 1641-4381. 2008, t. 43, pp. 5570 .

17. Mackevicius, J., Kazlauskiene, L., 2009. The fraud tree and its investigation in audit. Economics. ISSN 1392-1258. 2009, t. 85, pp. 90-101.

18. Mackevicius, J., Pranckeviciute, L., 2007. Public Audit System and Its Improvement. [Valstybinio audito sistema ir jos tobulinimas]. Monetary studies. ISSN 1392-2637. No. 1, pp. 45-61.

19. Maijoor, S., et al., 1995. Long-Term Concentration in the Dutch Audit Market: The Use of Auditor Association Membership Lists in Historical Research. Abacus 31, No. 2, pp. 152177. Business Source Complete, EBSCOhost (accessed September 21, 2010).

20. Oxera report: Ownership rules of audit firms and their consequences for audit market concentration prepared for DG market and services, October 2007: 164-200, available online at http://www.oxera.com (accessed September 1, 2010).

21. Palmrose, Z., 1986. Audit Fees and Auditor Size: Further Evidence. Journal of Accounting Research, pp. 97-110. 
22. Quick, R. \& Wolz, M., 1999. Concentration on the German audit market - an empirical analysis of the concentration on the German market for stock corporation audits, International Journal of Auditing, Vol. 3, pp. 175-89.

23. Schiff, A., Fried, H. D., 1976. Large Companies and the Big Eight: An Overview, Abacus.

24. The Code of Ethics of professional accountants, the international auditing standards available online at http://www.ifac.org (accessed September 1, 2010).

25. The Global Competitiveness Report 2009-2010. World Economic Forum, 2009, available online at http://www.weforum.org/en/media/publications/CompetitivenessReports/index.htm (accessed September 1, 2010).

26. The Global Competitiveness Report 2010-2011. World Economic Forum, 2010, available online at http://www.weforum.org/en/media/publications/CompetitivenessReports/index.htm (accessed September 1, 2010).

27. Zeff, S. A., Fossum, R. L., 1967. An Analysis of Large Audit Qients. The Accounting Review Vol. 42, No. 2.

28. Willekens, M., Achmadi, Ch., 2003. Pricing and supplier concentration in the private client segment of the audit market: market power or competition? International Journal of Accounting, Vol. 38, pp. 431-55.

29. Wolk, C. M., Michelson, S. E., Wooton, C. W., 2001. Auditor concentration and market shares in the US: 1988-1999 a descriptive note', British Accounting Review, Vol. 33, No. 2, pp. 157-74. 